4. Масколюнас Р. К., Лекис А. В., Коваленко М. Н. Биосинтез белка в бесклеточных белоксинтезирующих системах из миокарда кролика при тотальной ншемин // Биополимеры и клетка.-1989.-5, № 1.- С. $84-86$.

5. Масколюнас $P . K$. Структурно-функциональные изменения в пуле рибосом миокардиальных клеток кроликов при тотальной ишемни // Сб. науч. тр. 1-ой респ. конф. молодых учепьх медиков ЛитССР.-Kaупас, 1988-C. 54-57.

6. Morphological and biochemical changes in autolyzing dog heart muscle/L. C. Armiger, R. N. Seelye, V. M. Carnell et al. // Lab. Invest.-1976.-34, ^ 4.- P. 357-362.

7. Яоич $М$. П., Лерман $М$. И. Бесклеточная система белкового синтеза из сердечіюй мышцы кролика // Вопр. мед. химин.- 1976.- № 3.-С. 307-327.

8. Бернам A. E. Метод выделения полирибосом, свободиых и связанных с мембранами цитоптазматической сети // Соврем. методы в биохимии.- М. : Медицина, 1977.C. $300-303$.

?. Нзучение молекулярных механизмов гипоальбуминемии на модели экспериментального инфаркта миокарда / А. В. Лекис, Л. Ю. Лукошявичюс, М. И. Коваленко. О. В. Булдакова // Биополимеры и клетка.-1985-1, № 6-С. $322-327$.

10. Laemmli $U . K$. Cleavage of structural proteins during the assembly of the head of hacteriophage $T \cdot 1 / /$ Nature.- 1970.-227, N 5259.-P. $680-685$.

Ин-т молекуляр. бнологии и генстики

АН УCCP, Киев

Получено 20.03.89

\title{
ELECTROPHORETICAL ANALYSIS OF TRANSLATION \\ PRODUCTS IN THE CELL-FREE SYSTEMS \\ FROM NORMAL AND ISCHEMIC RABBIT MYOCARDIUM
}

R. K. Maskoliunas

Institute of Molecular Biology and Genetics, Academy of Sciences

of the Ukrainian SSR, Kiev

$\mathrm{S} 11 \mathrm{~mm}$ ary

The rate of radioactive amino acjd incorporation into translational product in the reconstructed protein-synthesizing cell-free systems, consisting of cytosol and polyribosonues from normal and ischemic myocardium is compared. The alteration in proteinsynthesizing aclivity is shown to depend mainly on the properties of polyribosomal preparations. Electrophoretical analysis of the translational products with subsequent fluorography has revealed redistribution of some protein fractions in the system from ischemic myocardium.

УДК 577.112 .088 .3

А. Д. Яремчук, М. А. Тукало, А. В. Коноваленко, С. П. Егорова, Г. Х. Мацука

\section{ВЫДЕЛЕНИЕ СЕРИЛ-ТРНК СИНТЕТАЗЫ И3 THERMUS THERMOPHILUS HB-27}

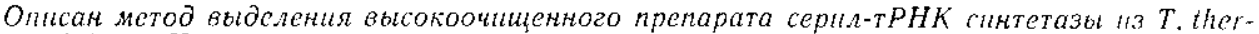
mophilus. Hспользовалt высаливанtе сульфатол аммония, хроматографию на Д.ЭА. ефорозе, оксиапатите, генарин-сефарозе и гидрофобную хролатографию на поливини.

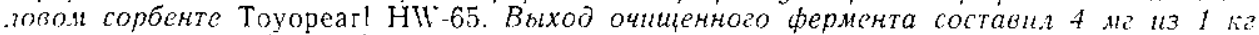

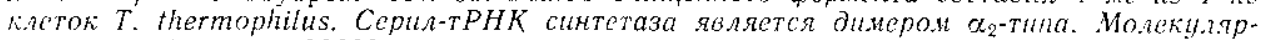
Han uacca рермента 90000

Аминоацил-тРНК синтетазы и тРНК являются уникальными объектами для изучсния молекулярных механизмов белково-пуклеинового взаимодейстия. В пастояцес время достигнуты определенные успехи в псслсдовании структуры тРНК - аминоацил-тРНК синтетазного қомплскса [1]. Однақо подобные работы проводились с тРНҚ первого класса, именцини короткую вариабельную пстлю. Экспериментальные же sанные по изучению взаимодействия аминоацил-тРНК синтетаз с тРНК второго класса (с длинпой вариабелыной петлей) крайне ограничепп. 
Важнейшим этапом на пути $\mathrm{k}$ пониманию механизма специфического взаимодсйствия тРНК и аминоацил-тРНК синтетаз являются структурные исследования этих макромолекул.

В данном сообщении описан метод выделения высокоочищенного препарата серил-тPHK синтетазы из T. thermophilus HB-27. тPHK указанной специфичности относится ко второму классу, а аминоацил-тРНК синтетазы из этого объекта обладают высокой термостабильностью, что позволяет использовать физические методы при изучении структуры этих ферментов.

Пострибосомный супернатант $T$. thermophilus любезно предоставлен М. Б. Гарбер (Ин-т белка АН СССР). Суммарный препарат тРНК Escherichia coli получен из ВНИИ прикл. биохимии (Олайне, ЛатвССР). Серил-тРНК синтетазную активность определяли по начальной скорости образования аминоацил-тРНК. Инкубационная смесь в 0,05 мл содержала 100 мM трис-HCl-буфер, pH 8,0, $10 \mathrm{mM} \mathrm{MgCl}_{2}$, 5 мM АТP, 10 мM KCl, 0,3 мM ${ }^{14} \mathrm{C}$-серин, 5 мг/мл суммарного препаnaта тPHK E. coli, 0,2 мг/мл бычьего сывороточного альбумина (БCA) н от 0,05 до 10 мкг белка (в зависимости от степени очистки фермента). Смесь никубировали в течение 30 с при $55^{\circ} \mathrm{C}$. Реакцию останавливали добавлением 200 мкл охлажденной $10 \%$-ной трихлоруксусной кислоты (ТХУ). Образовавшиеся осадки отмывали на миллипоровых фильтрах 50 ил $5 \%$-ной ТХУ. Радиоактивность проб определяли на спинтиляционном счетчике SL-30 фирмы «Intertechnique» (Франция). Mолекулярную массу серил-тРНK синтетазы устанавливали методом электрофорсза в полиакриламидном геле (ПААГ) в нативных условиях при разыых концентрациях геля [2], молекулярную массу субъединиц - п пощью электрофореза в ПААГ в присутствии DS-Na. 3 a единицу активности серил-тРНК синтетазы принимали количество фермента, катализирующее аминоацилирование 1 нмоль тPHKSer за 1 мин при $55^{\circ} \mathrm{C}$

В таблице представлены данные, характеризующие степень очистки серил-тРНК сиптетазы па каждой стадии выделения. На первой стацни отистки яспользовали высаливание пострибосомного суперпатанта сульфатом аммония (45\% насыщения). Полученный осадок диализовали гротив 50 мM трис-HCl-буфера, pH 7,8), содержащего 5 мМ $\mathrm{MgCl}_{2}, 5$ мM $\beta$-меркаптоэтанол, 0,1 м тилсульфонилфторид (ФМСФ) (буфер А) и наносили на колонку $(5 \times 50 \mathrm{~cm})$ с ДЭАЭ-сефарозой («Pharmacia», Швеция), уравновешснной буфером А. Элюцию проводили в этом же буфефе в градиенте концентрации $\mathrm{NaCl}$ от 0,03 до $0,3 \mathrm{M}$ (объем градиента 2,5 л). Фракцию с ДЭАЭ-сефарозы, обладаюшую серил-тРНК синтетазной активностью, высаливали сульфатом аммония (45\% насыщения) и хроматографировали на колонке $(2,5 \times 60 \mathrm{~cm})$ с поливиниловым copбентом Toyopearl HW-65 («Тоуо Soda», Япония) в буфере A в обратном градиенте концептрация сульфата аммония от 40 цо $10 \%$ пасыщения (объем гради-

Onuctia cepun-TPHK ClthteTazb T. thermophilus HB-27

Purification of seryl-tRNA synthetase from $T$. thermophilus HB-27

\begin{tabular}{|c|c|c|c|c|c|}
\hline Основные стадии очистки & $\begin{array}{l}\text { Общий } \\
\text { белок. } \\
\text { мг }\end{array}$ & $\begin{array}{l}\text { Общая } \\
\text { актив- } \\
\text { ность, } \\
\text { ед. акт. }\end{array}$ & $\begin{array}{c}\text { удельназ } \\
\text { актив. } \\
\text { ность. } \\
\text { ед. } \\
\text { акт./мг }\end{array}$ & $\begin{array}{l}\text { Стеиень } \\
\text { очистки }\end{array}$ & $\begin{array}{l}\text { Вы- } \\
\text { ход, } \\
\%\end{array}$ \\
\hline \multicolumn{6}{|l|}{ Высаливание пострибосомного супер- } \\
\hline сышения & 23690 & 18952 & 0.8 & 1,0 & 100 \\
\hline Хроматография на ДЭАЭ-сефарозе & 2936 & 19378 & 6,6 & 8,3 & 102 \\
\hline Гидрофобная хроматография на Тоуо- & & & & & 40 \\
\hline $\begin{array}{l}\text { pearl HW-65 } \\
\text { Хроматография на оксиапатите }\end{array}$ & $\begin{array}{l}740 \\
218\end{array}$ & $\begin{array}{l}9324 \\
7521\end{array}$ & $\begin{array}{l}12,6 \\
34.5\end{array}$ & $\begin{array}{l}15,7 \\
43,1\end{array}$ & $\begin{array}{l}40 \\
40\end{array}$ \\
\hline Pexpoмaтографня на Toyopearl HW-65 & 77 & 7423 & $\begin{array}{l}3+, 4 \\
96,4\end{array}$ & 120,5 & 39 \\
\hline Хроматограффня на гепарин-сефрарозе & 4 & 6004 & 1501 & 1876 & 32 \\
\hline
\end{tabular}


ента 1,8 л). Фракцию, содержашую серил-тРНК синтетазу, диализовали в течение 20 ч против 10 мМ калий-фосфатного буфера, $\mathrm{pH} 7,8$, содержащего 5 мM $\beta$-меркаптоэтанол, 0,1 мM азид натрия, 0,1 мM $Ф М С Ф$ (буфер Б) и наносили на колонку $(2,5 \times 55 \mathrm{~cm})$ с оксиапатитом («Bio-Rad», CША), уравновешенным этим же буфером. Фермент элюнровали в градиенте концентрации калий-фосфатного буфера от 0,01

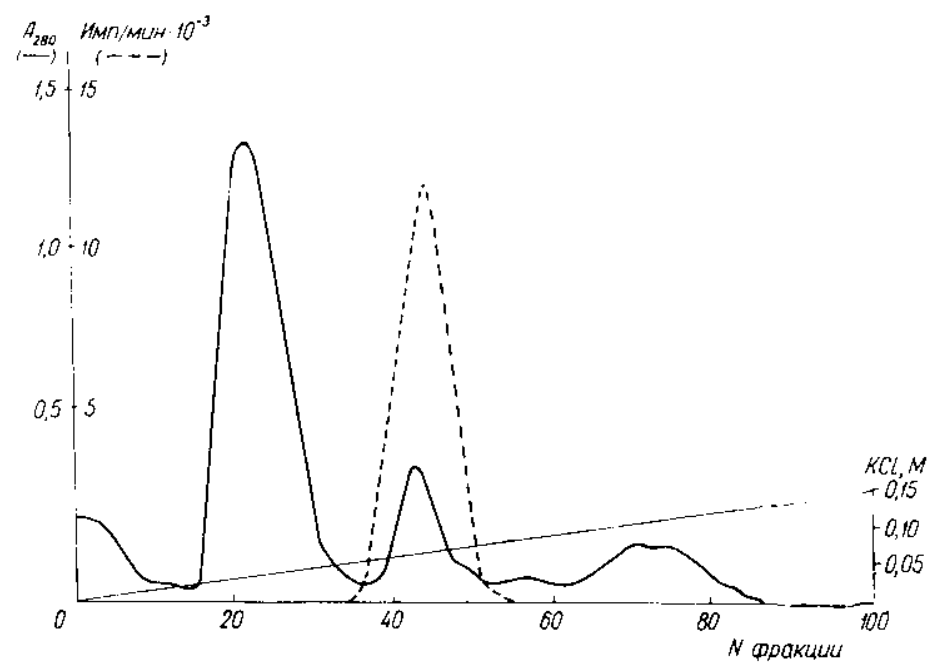

Рнс. 1. Хроматография серил-тРНК синтетазы $T$. thermophilus на гепарин-сефарозе Fig. 1. Chromatography of seryl-tRNA synthetase from $T$. thermophilus on heparin-sepnarose

Рнс. 2. Электрофорез в ПААГ в присутствии DS-Na: 1 смесь стандартных белков; 2 -- сернл-тPHК синтетаза $T$. thermophilus после хроматографии на гепарин-сефарозе Fig. 2. Polyacrylamide gel electrophoresis in the presence of sodium dodecyl sulfate: $1 \rightarrow$ molecular mass markers; $2-$ seryl-tRNA synthetase of $T$. thermophilus after chromatography on heparin-sepharose column

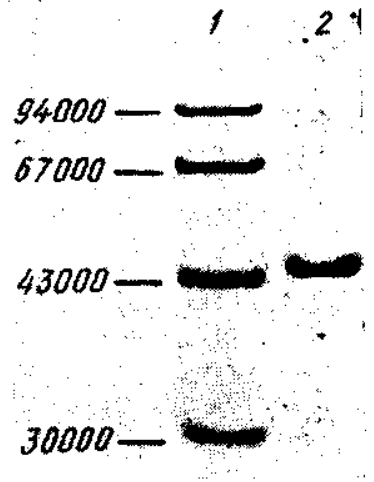

до $0,2 \mathrm{M}$ (объем градиента $3 \mathrm{л}$ ). Серил-тРНК синтетазу высаливали сульфатом аммония и проводили рехроматографию на Toyopearl HW-65 в тех же условиях, что и первичную хроматографию. Окончательная очистка серил-тРНК синтетазы была осуществлена на гепаринсефарозе (рис. 1). Белок после диализа хроматографировали на колонке $(0,5 \times 15 \mathrm{~cm})$ с гепарин-сефарозой («Рharmacia», Швеция), уравновешенной буфером $A$, в градиенте копцештрации $\mathrm{KCl}$ от 0 до $0,25 \mathrm{M}$ (объсм градиента 0,5 л).

Таким образом, из 1 кг бактериальной массы получено 4 мг препарата серил-тPНК синтетазы - практически в индивидуальном состоянии, судя по данным электрофореза (рис. 2). О высокой степени чистоты полученного препарата фермента свидетельствуют также данные об отсутствии примесей других аминоацил-тРНК синтетаз, содержание которых определяли, используя смесь ${ }^{14} \mathrm{C}$-аминокислот гидролизата хлореллы и избыток ${ }^{12} \mathrm{C}$-серина.

Изучена также температурная зависимость скорости реакции аминоацилирования, катализируемой серил-тPНК сиптетазой $T$. thermophilus. Установлено, что температурный оптимум находится в области 
$70{ }^{\circ} \mathrm{C}$. Значение удельной активности полученного препарата серилтРНК синтетазы при оптимальных условиях реакции аминоацилирования и при использовании в качестве субстрата гомологичной тРНК из T. thermophilus coставляет 2552 ед/мг. Молекулярная масса фермента по данным электрофореза в МААГ в нативных условиях - 90000. Серил-тРНК синтетаза представляет собой структурный димер, состоящий из двух идентичных субъединиц с молекулярными массами 46000 (рис. 2). Аналогичная олигомерная структура и близкие молекулярпые массы показаны для серил-тРНК синтетаз из других прокарнотичсских обтектов $[4,5]$.

\section{СПLІСОК ЛИТЕРАТУРЫ}

1. Kucenes .7. Л., Фаворова О. О., Лаврик О. Н. Бносинте: беліка от аминокимиот If) аминоацил-тPHК.-M. : Наука, 1984.-480 c.

2. Hedrick J. L., Smith A. J. Estimation of molecular weight by polyacrylamide gel e.cetrophoresis // Arch. Biochem. and Biophys.-1968.-126, N 1.- P. 155-164.

3. Ileber $K$. Osborn $M$. The reability of molecular weight by dodecylsulfate-polyacrylanide gel electrophoresis // J. Biol. Chem.-1969.-244, $N$ 16.- P. 4406-4412.

1. Katze J.R. Konigsberg $W$. Purification and properties of seryl transfer ribonucle:c acid syuthetase from Escherichia coli// Ibid.-1970.-245, N 5.- P. 923-930.

5. Sunuelsson T., Lundvik $L$. Purification and some properties of asparagine, serinc and Viline: ARNA ligases from Bacillus stearothermophilus // lbid.-1978, -253, N 10 P. 7033-7039.

Ин-т молекуляр. бнологии и генетики

АН УССР, Киев

По.учено 10.03.89

\section{ISOLATION OF SERYL-TRNA SYNTHETASE FROM \\ TIERMUS THERMOPHILUS HB- 27}

A. D. Yaremchuk, M. A. Tukalo, A. V. Konovalenko, S. P. Egorova,

G. Kh. Matsuka

Institute of Molecuiar Biology and Genetics Academy

of Sciences of the Ukrainian SSR, Kiev

sum mary

A method to isolate seryl-tRNA synthetase from Thermus thermophilus is described. It includes ammonium sulfate fractionation, chromatography on DEAE-sepharose, liydroxyapatite, heparine-sepharose and hydrophobic chromatography on polyvinyl sorbent Toyopearl HW-65. The yield of highly purified enzyme was $4 \mathrm{mg}$ from $1 \mathrm{~kg}$ of $T$. thermophilus cells. Seryl-tRNA synthetase is a dimer protein ( $\alpha_{2}$ type) with molecular mass (1) $90 \mathrm{kDa}$. 